\title{
Copper-Modified Low Density Lipoprotein from Diabetic Patients Enhances Cholesteryl Ester Synthesis by Mouse Peritoneal Macrophages
}

\author{
Kazuko Hiramatsu, ${ }^{1, *}$ László Prónai, ${ }^{1}$ Hiroe Nakazawa, ${ }^{2}$ \\ and Paul K. NAKANE ${ }^{3}$ \\ ${ }^{1}$ Department of Internal Medicine, ${ }^{2}$ Department of Physiology, \\ Tokai University School of Medicine, Isehara 259-11, Japan \\ ${ }^{3}$ Department of Anatomy, Nagasaki University, \\ School of Medicine, Nagasaki 852, Japan
}

(Received December 12, 1991)

Summary In this study, the capability of superoxide production by LDL either without stimulation or under the stimulation of Fe-ADP and the manner of modification of low density lipoprotein (LDL) by copper $\left(\mathrm{Cu}^{++}\right)$in diabetic patients were examined and compared with those of healthy subjects. The amount of superoxide generated by diabetic LDL was similar to that of healthy subjects both at the basal level and following stimulation by Fe-ADP. LDL from healthy subjects and diabetic patients was modified in the presence of $10 \mu \mathrm{M} \mathrm{CuSO}_{4}$. When the level of thiobarbituric acid-reactive substance was determined in the $\mathrm{Cu}^{++}$-modified LDL, no difference was found. On the other hand, when the incorporation of $\left[{ }^{14} \mathrm{C}\right]$ oleate into cholesteryl ester (CE) by mouse peritoneal macrophages was stimulated by the $\mathrm{Cu}^{++}$-modified LDL, we found that the modified diabetic LDL significantly enhanced the CE synthesis compared with the modified healthy LDL $(p<0.01)$. To clarify the mechanism of the enhanced $\mathrm{CE}$ synthesis, the rate of degradation of $\left[{ }^{125} \mathrm{I}\right] \mathrm{Cu}^{++}$-modified diabetic LDL was measured. We found that this rate was similar to that of healthy subjects. These data suggest that the degree of oxidation does not differ among patients although diabetic LDL is modified by $\mathrm{Cu}^{++}$in a manner such that it preferentially promotes the activity of $\mathrm{CE}$ synthesis in macrophages by some unknown intracellular metabolic mechanism.

Key Words: diabetes, superoxide, LDL, foam cell, macrophages

\footnotetext{
${ }^{*}$ To whom correspondence should be addressed.
} 
The incidence of atherosclerosis is high in diabetic patients [1-3], and the reason for this is not clear. However, it has been speculated that various atherogenic factors work cooperatively or synergistically to promote the development of atherosclerosis.

In the present study, two specific atherogenic factors were focused upon. The first is the superoxide generated by diabetic LDL, because it has been reported that the free radical accelerates the development of atherosclerosis in several ways [4]. The second is the manner of modification of low density lipoprotein (LDL). Modified LDL is involved in the deposition of cholesteryl ester (CE) in macrophages [5-7]. Macrophages are thought to be the precursors of most of the lipid-laden foam cells characteristic of the early atheromatous lesion $[8,9]$, and $\mathrm{CE}$ synthesis is associated with the deposition of $\mathrm{CE}$ in macrophages [5]. Our results indicate that diabetic $\mathrm{LDL}$ is modified by $\mathrm{Cu}^{++}$in a unique manner whereby it significantly enhances the synthesis of CE by macrophages.

\section{MATERIALS AND METHODS}

Subjects. Two groups of subjects were studied after informed consent had been obtained: 5 healthy individuals comprising 2 males and 3 females (healthy group) and 11 diabetic patients comprising 7 males and 4 females (diabetic group). All diabetic patients except one had non-insulin-dependent diabetes mellitus and were diagnosed based upon the criteria of the National Diabetes Data Group concerning the $75-\mathrm{g}$ oral glucose tolerance test [10]. Blood glucose of diabetic patients was controlled with a stable treatment regimen for 4 months before the experiments, and glucose levels were stable at the time of blood withdrawal. Five patients in the diabetic group were treated with insulin, and the other 6 received oral hypoglycemic agents. None of the diabetic patients had complications of atherosclerosis such as ischemic heart disease or cerebral vascular disease. Six of the 11 diabetic patients had hypertriglyceridemia (plasma triglyceride $>1.69$ SI units).

Low density lipoprotein separation. Following an overnight fast, $20 \mathrm{ml}$ blood was withdrawn from each subject. Ethylenediaminetetraacetic acid (EDTA) was added to obtain a final concentration of $1 \mathrm{mg} / \mathrm{ml}$. Low density lipoprotein (LDL) $(1.019<d<1.063)$ was separated by ultracentrifugation [11]. Protein was measured by the method of Lowry et al. [12].

Superoxide generation from $L D L$. EDTA was first removed from the LDL by dialysis against $10 \mathrm{~mm}$ sodium phosphate buffer (pH 7.4) (PBS) containing 150 $\mathrm{mm} \mathrm{NaCl}$. Measurement of superoxide was performed at the basal level and following the stimulation by Fe-ADP in five normal LDL samples and five diabetic LDL samples. The experiment was performed in the dark room and finished within $4 \mathrm{~h}$. Employing one LDL sample, the basal photon level was followed from the beginning of the experiment until the end. The value of the basal photon count did not alter during $4 \mathrm{~h}$ of the experiment. The superoxide 
generation was determined by the 2-methyl-6-phenyl-3,7-dihydroimidazo $[1,2 \alpha]$ pyrazin-3-one (MCLA)-dependent chemiluminescence method [13]. The system containing $4 \mu \mathrm{M}$ MCLA and $100 \mu \mathrm{g} \mathrm{LDL}$ (final concentration: $33 \mu \mathrm{g} / \mathrm{ml}$ of LDL protein) in $3 \mathrm{ml}$ of $10 \mathrm{mM}$ HEPES ( $\mathrm{pH} \mathrm{7.4)} \mathrm{was} \mathrm{incubated} \mathrm{for} 5 \mathrm{~min}$ at $37^{\circ} \mathrm{C}$, and chemiluminescence was detected. The addition of $8.6 \mu \mathrm{M}$ Fe-ADP complex to the system caused an immediate increase in the photon count; this increase could be completely inhibited by 50 units of superoxide dismutase (SOD). The level of SOD-inhibited photon count was used for the estimation of both the basal and Fe-ADP complex-stimulated superoxide release from LDL.

Modification of $\mathrm{LDL}$ by $\mathrm{CuSO}_{4}$. To determine the susceptibility of LDL to modification, we used LDL from which EDTA had been eliminated by dialysis. LDL was then oxidized in the presence of $10 \mu \mathrm{M} \mathrm{CuSO}_{4}$ for $12 \mathrm{~h}$ by the method of Heinecke et al. [14]. Lipid peroxide formation was estimated by the measurement of thiobarbituric acid-reactive substances (TBARS) according to the method of Schuh et al. [15]. The optical density of the supernatant was determined at 532 $\mathrm{nm}$ and was compared with that of a freshly prepared malondialdehyde (MDA) standard [16]. The results were expressed as MDA equivalents per milligram of LDL protein. The oxidized LDL was dialyzed in RPMI 1640 and used in the following procedure.

$\left[{ }^{14} \mathrm{C}\right]$ oleate incorporation into cholesteryl ester by mouse peritoneal macrophages. Resident peritoneal cells from unstimulated mice were harvested in PBS as described by Edelson and Cohn [17]. The cells were plated in 35-mm wells at a concentration of $3 \times 10^{6}$ cells/well and were cultured for $18 \mathrm{~h}$ in Dulbecco's modified Eagle's medium containing $10 \%$ fetal calf serum. Then the culture medium was removed and the adherent macrophages were washed twice with RPMI 1640. One milliliter of RPMI 1640 was added and cells were cultured for 6 $\mathrm{h}$ in the presence of both $20 \mathrm{nmol}\left[{ }^{14} \mathrm{C}\right]$ oleate (NEN Research Products, Boston, MA) and $50 \mu \mathrm{g}$ of modified LDL. After incubation, the medium was removed and the cells were washed twice with PBS. Lipids were extracted with hexane and isopropanol $(3: 2, \mathrm{v} / \mathrm{v})$. After the solvent had been evaporated under $\mathrm{N}_{2}$ gas, the extracted lipid was separated by silica gel $G$ thin-layer chromatography. The chromatogram was developed in heptane : diethyl ether: acetic acid $(90: 10: 1)$. The CE spot was identified by use of iodine vapor and was cut from the chromatogram. Scintillation solution (Aquasol 2, NEN Research Products) was added, and the radioactivity was counted in a liquid scintillation counter. Correction for procedural losses was made by the addition of $\left[{ }^{3} \mathrm{H}\right]$ cholesteryl oleate (NEN Research Products) to the well prior to the lipid extraction. One milliliter of 0.2 $\mathrm{M} \mathrm{NaOH}$ was added to the well in which cells remained for the measurement of cell protein [12]. Triplicate dishes of cells were used for each LDL sample.

Metabolism of $\left[{ }^{125} I\right]$-copper-modified normal $L D L$ and $\left[{ }^{125} I\right]$-coppermodified diabetic $L D L$. Three samples each were chosen at random from 5 $\mathrm{Cu}^{++}$-modified normal $\mathrm{LDL}$ and $5 \mathrm{Cu}^{++}$-modified diabetic LDL that were prepared as described above. Those six samples were labeled with [ $\left.{ }^{125} I\right]$ by the iodine

Vol. 12, No. 2, 1992 
monochloride method [18]. Mouse peritoneal macrophages were prepared as described above. [ $\left.{ }^{125} \mathrm{I}\right]$-labeled $\mathrm{Cu}^{++}$-modified normal LDL or [ $\left.{ }^{125} \mathrm{I}\right]$-labeled $\mathrm{Cu}^{++}$-modified diabetic LDL was added at a concentration of $50 \mu \mathrm{g} / \mathrm{ml}$, and the amounts of degradation and cell association were measured after a 6-h incubation as described previously [19].

Miscellaneous analysis. Fasting plasma glucose, total cholesterol, triglyceride, and hemoglobin $\mathrm{A}_{1 \mathrm{c}}$ were measured in the Tokai University Hospital Central Laboratory by commonly used procedures.

Statistical methods. Comparisons between the groups were made by the Mann-Whitney non-parametrical statistical analysis [20]. Correlation coefficients were determined by a standard statistical method.

\section{RESULTS}

The diabetic group had a higher fasting plasma glucose level accompanied by a higher level of hemoglobin $A_{1 c}$ than the healthy group (Table 1). The amount of superoxide generated from LDL was measured both at the basal level and following the stimulation by Fe-ADP. The photon count increased approximately ten-fold following the stimulation by Fe-ADP (Table 2). When the photon count of the healthy and diabetic groups was compared, no significant difference was observed either at the basal level or after the Fe-ADP stimulation. The levels of TBARS were measured pre and post modification by $\mathrm{Cu}^{++}$. The level of TBARS in $\mathrm{LDL}$ following $\mathrm{Cu}^{++}$modification was more than the original value without $\mathrm{Cu}^{++}$modification (Table 3). When the level of TBARS between the two groups was compared, no significant difference was observed either before or after $\mathrm{Cu}^{++}$ modification. When the TBARS levels of each sample following $\mathrm{Cu}^{++}$modification were plotted against the original TBARS values without modification, no significant correlation was observed. When the effect of $\mathrm{Cu}^{++}$-modified LDL on the activity of CE synthesis by macrophages was tested, we found that the CE

Table 1. Plasma glucose and $\mathrm{HbA}_{1 \mathrm{C}}$ in healthy subjects and diabetic patients.

\begin{tabular}{lrcc}
\hline Group & $n$ & Glucose (SI units) & $\operatorname{HbA}_{1 \mathrm{C}}(\%)$ \\
\hline Healthy & 5 & $4.9(4.5-5.5)$ & $5.1(4.8-5.3)$ \\
Diabetic & 11 & $10.4(5.2-17.4)^{*}$ & $8.1(7.3-12.4)^{* *}$ \\
\hline
\end{tabular}

Values are median with ranges in parentheses. Normal range of hemoglobin $\mathrm{A}_{1 \mathrm{c}}\left(\mathrm{HbA}_{1 \mathrm{C}}\right)$ is 5.2-6.7\%. ${ }^{*} p<0.001,{ }^{* *} p<0.0009$, diabetic vs. healthy group.

Table 2. Photon count of LDL.

\begin{tabular}{lcc}
\hline & Healthy subjects & Diabetic patients \\
\hline Number & 5 & 5 \\
Basal photon count & $10(10-20)$ & $9(6-11)$ \\
Photon count stimulated by Fe-ADP & $160(94-177)$ & $131(91-165)$ \\
\hline
\end{tabular}

Values are median with ranges in parentheses. 
Table 3. TBARS in LDL with and without modification by $\mathrm{Cu}^{++}$.

\begin{tabular}{lrcc}
\hline \multirow{2}{*}{ Group } & \multirow{2}{*}{$n$} & \multicolumn{3}{c}{ TBARS in LDL } \\
\cline { 3 - 4 } & & Pre-modification (nmol/mg protein) & Post-modification (nmol/mg protein) \\
\hline Healthy & 5 & $1.33(1.15-1.71)$ & $31.35(19.56-59.80)$ \\
Diabetic & 11 & $1.58(1.36-2.06)$ & $38.23(23.63-69.45)$ \\
\hline
\end{tabular}

Values are median with ranges in parentheses.

Table 4. Cholesteryl ester synthesis by macrophages in the presence of copper-modified LDL.

\begin{tabular}{lrc}
\hline Group & $n$ & $\begin{array}{c}\left.{ }^{14} \mathrm{C}\right] \text { oleate incorporation into cholesteryl ester } \\
(\mathrm{nmol} / \mathrm{mg} \text { of cellular protein } / 6 \mathrm{~h})\end{array}$ \\
\hline Healthy & 5 & $1.89(1.41-3.06)$ \\
Diabetic & 11 & $3.42(2.01-7.05)^{*}$ \\
\hline
\end{tabular}

Values are median with ranges in parentheses. ${ }^{*} p<0.01$, healthy vs. diabetic group.

Table 5. Degradation and internalization of $\left[{ }^{125} I\right]$ copper-modified LDL by macrophages.

\begin{tabular}{lccc}
\hline Source & $n$ & $\begin{array}{c}\text { Degradation } \\
(\mu \mathrm{g} / \mathrm{mg} \text { protein } / 6 \mathrm{~h})\end{array}$ & $\begin{array}{c}\text { Cell association } \\
(\mu \mathrm{g} / \mathrm{mg} \text { protein } / 6 \mathrm{~h})\end{array}$ \\
\hline $\mathrm{Cu}^{++}$healthy LDL & 3 & $9.53 \pm 1.44$ & $0.013 \pm 0.001$ \\
$\mathrm{Cu}^{++}$diabetic LDL & 3 & $9.49 \pm 0.66$ & $0.013 \pm 0.001$ \\
\hline
\end{tabular}

All values are expressed as mean $\pm \mathrm{SD}$.

synthesis was significantly higher in the cells treated with modified diabetic-group LDL than in those treated with the healthy-group modified LDL $(p<0.01)$ (Table 4). No significant correlation was obtained between $C E$ synthesis by macrophages and TBARS levels in $\mathrm{Cu}^{++}$-modified LDL. The relationship of the enhanced CE synthesis by $\mathrm{Cu}^{++}$-modified diabetic LDL and the $\mathrm{HbA}_{1 \mathrm{C}}$ level was also analyzed; however, no significant relationship was found.

To clarify the mechanism of the enhanced CE synthesis in the presence of $\mathrm{Cu}^{++}$-modified diabetic LDL, we examined the metabolism of apoprotein $\mathrm{B}$ in $\mathrm{Cu}^{++}$-modified diabetic LDL by macrophages. $\mathrm{Cu}^{++}$-modified diabetic LDL was labeled with $\left[{ }^{125} \mathrm{I}\right]$, and the levels of internalization and degradation were measured and compared with those of $\left[{ }^{125} \mathrm{I}\right]$-labeled $\mathrm{Cu}^{++}$-modified normal LDL. The levels of both degradation and cell association were found to be similar (Table 5).

Since 6 diabetic patients had hypertriglyceridemia, a comparison study was also performed in all parameters described above between the two diabetic groups with and without hypertriglyceridemia. No significant difference was observed.

\section{DISCUSSION}

The present study was undertaken to determine the atherogenic factors that are unique to diabetes mellitus. Two atherogenic factors were examined, the first 
being the capability of superoxide production by diabetic LDL. Since it has been reported that the free radical accelerates the development of atherosclerosis in several ways [4], we attempted to measure the superoxide generation in patients in whom atherosclerosis is common. We found that monocytes generate a greater amount of superoxide in those patients [21] and that the superoxide generated by monocytes is partially responsible for the oxidation of LDL [22]. However it still remains unclear as to whether or not LDL alone is capable of generating superoxide. Recently, Sakurai et al. [13] reported that glycated polypeptide generates superoxide and that this action is accelerated by the presence of iron. Therefore, we tested the possibility that glycosylated apoprotein B of LDL in diabetes produces a greater amount of superoxide. We found that diabetic LDL and healthy LDL generate superoxide to a similar extent. A possible reason is that the degree of glycosylation in diabetic LDL in vivo [23] seems insufficient compared with that of the in vitro system [13].

The second purpose of the present study was to investigate the manner of LDL-modification by copper. The activity of CE synthesis by macrophages in the presence of $\mathrm{Cu}^{++}$-modified diabetic LDL was increased independent of the level of TBARS. LDL oxidation by $\mathrm{Cu}^{++}$and metabolism by macrophages have been reported by Steinbrecher et al. [24]. $\mathrm{Cu}^{++}$-modified $\mathrm{LDL}$ is taken up by scavenger receptors in macrophages and digested in lysosomes; and the hydrolyzed free cholesterol is re-utilized for the synthesis of new CE. This research group showed that the degree of oxidation in LDL had a linear relationship with both the amount of the degradation of [ $\left.{ }^{125} \mathrm{I}\right]$-labeled $\mathrm{Cu}^{++}$-modified LDL and CE synthesis by macrophages. In that system, LDL's oxidized to various degrees were prepared from healthy LDL from a single source by alteration of the experimental conditions. In contrast, in the present study, there was no direct correlation between TBARS and CE synthesis. A possible explanation is as follows: The measurement of TBARS may be a very crude method of assessment of oxidation and may not precisely monitor the changes critical to determining cellular CE synthesis, as Jialal et al., have already reported [25]. This wide variation may make it difficult to analyze the relationship between LDL oxidation and CE synthesis.

In order to clarify the mechanism of enhancement of CE synthesis by the $\mathrm{Cu}^{++}$-modified diabetic LDL, we examined the metabolism of apoprotein $\mathrm{B}$ of $\mathrm{Cu}^{++}$-modified diabetic LDL. Regarding the metabolism of glycosylated LDL without $\mathrm{Cu}^{++}$modification, it remains controversial as to whether the glycosylated LDL alone is capable of enhancing the CE synthesis. The LDL that is extensively glycosylated in vitro has been shown to enhance the $\mathrm{CE}$ synthesis by human monocyte-derived macrophages [26] but not that by murine macrophages [27, 28]. Therefore, in the present study employing mouse peritoneal macrophages, the modification by $\mathrm{Cu}^{++}$was added to diabetic LDL, and this procedure successfully led to the enhancement of CE synthesis. When the trichloroacetic-acid-soluble products were measured, indicating the degradation of $\left[{ }^{125} \mathrm{I}\right]$-labeled apoprotein in $\mathrm{Cu}^{++}$-modified diabetic LDL, the amount of degradation was the same as that of 
$\mathrm{Cu}^{++}$-modified normal LDL. This leads us to speculate that some alteration in the lipid part may be responsible for the enhanced CE synthesis. It has been reported that CE synthesis is increased by 7-ketocholesterol [29] and decreased by 7-hydroxycholesterol [30]. Thus there remains the possibility that oxidized diabetic LDL may contain a different mixture of oxidized lipids whose net effect may stimulate the $\mathrm{CE}$ synthesis more. As another possibility, the $\mathrm{CE}$ content of oxidized LDL may be decreased following the procedure of oxidation. It may possibly be decreased less in oxidized diabetic LDL than in oxidized normal LDL, thus leading to apparently greater CE synthesis with oxidized diabetic LDL. To assess these possibilities, further study is required.

The level of $\mathrm{HbA}_{1 \mathrm{C}}$ is known to correlate with the degree of glycosylation of LDL [23]; however, the CE synthesis was not significantly related to the level of $\mathrm{HbA}_{1 \mathrm{C}}$. Thus, the extension of glycosylation does not account for the enhancement of CE synthesis; however, glycosylation does seem to be a minimum requirement.

In the present experimental system, $\mathrm{Cu}^{++}$was employed to produce free radicals. However, it has also been shown that free radicals are released from several types of cells that constitute the arteries, such as endothelial cells [31] and arterial smooth muscle cells [14]. Thus, diabetic LDL may be modified by these cells in vivo, leading to the higher level of $\mathrm{CE}$ deposition in macrophages. In a previous serial study to determine disease-specific atherogenic factors, several factors were found to be unique to hypertriglyceridemia $[19,21,32]$. However, in the present study we found that the manner of $\mathrm{LDL}$ modification by $\mathrm{Cu}^{++}$was independent of hypertriglyceridemia.

We conclude that the altered manner of LDL modification in diabetes mellitus may accelerate the development of atherosclerosis, working cooperatively or synergistically with other previously known atherogenic factors [33].

\section{REFERENCES}

1. Garcia, M.J., MacNamara, P.M., Gordon, T., and Kannel, W.B. (1974): Morbidity in diabetics in the Framingham population: Sixteen-year follow-up study. Diabetes, 23, 105111.

2. Santen, R.J., Willis, P.W., and Fajans, S.S. (1972): Atherosclerosis in diabetes mellitus: Correlations with serum lipid levels, adiposity and serum insulin levels. Arch. Intern. Med., 130, 833-843.

3. Fontbonne, A., Eschwege, E., Cambien, F., Richard, J.-L., Ducimetière, P., Thibult, N., and Warnet, J.-M. (1989): Hypertriglyceridemia as a risk factor of coronary heart disease mortality in subjects with impaired glucose tolerance or diabetes. Diabetologia, 32, 300-304.

4. Steinberg, D., Parthasarathy, S., Carew, T.E., Khoo, J.C., and Witztum, J.L. (1989): Beyond cholesterol: Modification of low-density lipoprotein that increases its atherogenicity. $N$. Engl. J. Med., 320, 915-924.

5. Brown, M.S., Goldstein, J.L., Krieger, M., Ho, Y.K., and Anderson, R.G.W. (1979): Reversible accumulation of cholesteryl esters in macrophages incubated with acetylated lipoproteins. J. Cell. Biol., 82, 597-613.

6. Fogelman, A.M., Schechter, I., Seager, J., Hokom, M., Child, J.S., and Edwards, P.A. (1980): Malondialdehyde alteration of low density lipoprotein leads to cholesteryl ester

Vol. 12, No. 2, 1992 
accumulation in human monocyte-macrophages. Proc. Natl. Acad. Sci. U.S.A., 77, 22142218.

7. Henriksen, T., Mahoney, E.M., and Steinberg, D. (1981): Enhanced macrophage degradation of low density lipoprotein previously incubated with cultured endothelial cells: Recognition by receptor for acetylated low density lipoproteins. Proc. Natl. Acad. Sci. U.S.A., 78, 6499-6503.

8. Ross, R. (1981): Atherosclerosis: A problem of the biology of the arterial wall cells and their interaction with blood components. Arteriosclerosis, 1, 293-311.

9. Pitas, R.E., Innerarity, T.L., and Mahley, R.B. (1983): Foam cells in explants of atherosclerotic rabbits aortas have receptors for beta-very low density lipoproteins and modified low density lipoproteins. Arteriosclerosis, 3, 1-12.

10. National Diabetes Data Group (1979): Classification and diagnosis of diabetes mellitus and other categories of glucose intolerance. Diabetes, 28, 1039-1057.

11. Lindergren, F.T., and Jensen, L.C. (1972): The isolation and quantitative analysis of serum lipoproteins, in Blood Lipids and Lipoproteins: Quantitation, Composition and Metabolism, ed. by Nelson, G.J., Wiley Interscience Inc., New York, pp. 181-274.

12. Lowry, O.H., Rosebrough, N.J., Farr, A.L., and Randall, R.J. (1951): Protein measurement with the folin phenol reagent. J. Biol. Chem., 193, 265-275.

13. Sakurai, T., Sugioka, K., and Nakano, M. (1990): $\mathrm{O}_{2}{ }^{-}$generation and lipid peroxidation during the oxidation of a glycated polypeptide in the presence of iron-ADP. Biochim. Biophys. Acta, 1043, 27-33.

14. Heinecke, J.W., Rosen, H., and Chait, A. (1984): Iron and copper promote modification of low density lipoprotein by human arterial smooth muscle cells in culture. J. Clin. Invest., 74, 1890-1894.

15. Schuh, J., Fairclough, G.F., and Haschemeyer, R.H. (1978): Oxygen-mediated heterogeneity of apo-low density lipoprotein. Proc. Natl. Acad. Sci. U.S.A., 75, 3173-3177.

16. Smith, J.B., Ingerman, G.M., and Silver, M.J. (1976): Malondialdehyde formation as an indicator of prostaglandin production by human platelets. J. Lab. Clin. Med., 88, 167-172.

17. Edelson, P.J., and Cohn, Z.A. (1976): Purification and cultivation of monocytes and macrophages, in In Vitro Methods in Cell-Mediated and Tumor Immunity, ed. by Bloom, B.R. and David, J.R., Academic Press, Inc., New York, pp. 333-340.

18. Langer, T., Strober, W., and Levy, R.L. (1972): The metabolism of low density lipoprotein in familial type II hyperlipoproteinemia. J. Clin. Invest., 51, 1528-1536.

19. Hiramatsu, K., Bierman, E.L., and Chait, A. (1985): Metabolism of low density lipoprotein from patients with diabetic hypertriglyceridemia by cultured human skin fibroblasts. Diabetes, 34, 8-14.

20. Zar, J.H. (1984): Biostatistical Analysis, Second Edition, Prentice-Hall, Englewood Cliffs, N.J., 139 pp.

21. Hiramatsu, K., and Arimori, S. (1988): Increased superoxide production by mononuclear cells of patients with hypertriglyceridemia and diabetes. Diabetes, 37, 832-837.

22. Hiramatsu, K., Rosen, H., Heinecke, J.W., Wolfbauer, G., and Chait, A. (1987): Superoxide initiates oxidation of low density lipoprotein by human monocytes. Arteriosclerosis, 7, 5560 .

23. Nestler, J.E., Clore, J.N., and Blackard, W.G. (1988): Non-enzymatic glycosylation of low density lipoprotein. Results of an affinity chromatography method. Diabetologia, 31, 126128.

24. Steinbrecher, U.P., Parthasarathy, S., Leake, D.S., Witztum, J.L., and Steinberg, D. (1984): Modification of low density lipoprotein by endothelial cells involves lipid peroxidation and degradation of low density lipoprotein phospholipids. Proc. Natl. Acad. Sci. U.S.A., 81, 3883-3887.

25. Jialal, I., Freeman, D.A., and Grundy, S.M. (1991): Varying susceptibility of different low density lipoproteins to oxidative modification. Arterioscler. Thromb., 11, 482-488.

26. Lopes-Virella, M.F., Klein, R.L., Lyons, T.J., Stevenson, H.C., and Witztum, J.L. (1988): 
Glycosylation of low-density lipoprotein enhances cholesteryl ester synthesis in human monocyte-derived macrophages. Diabetes, 37, 550-557.

27. Witztum, J.L., Mahoney, E.M., Branks, M.J., Fisher, M., Elam, R., and Steinberg, D. (1982): Nonenzymatic glucosylation of low density lipoprotein alters its biological activity. Diabetes, 31, 283-291.

28. Gonen, B., Baenziger, J., Schonfeld, G., Jacobson, D., and Farrar, P. (1981): Nonenzymatic glycosylation of low density lipoproteins in vitro. Diabetes, 30, 875-878.

29. Zhang, H., Basra, H.J., and Steinbrecher, U.P. (1990): Effects of oxidatively modified LDL on cholesterol esterification in cultured macrophages. J. Lipid Res., 31, 1361-1369.

30. Jialal, I., and Chait, A. (1989): Differences in the metabolism of oxidatively modified low density lipoprotein and acetylated low density lipoprotein by human endothelial cells: Inhibition of cholesterol esterification by oxidatively modified low density lipoprotein. $J$. Lipid Res., 30, 1561-1568.

31. Henriksen, T., Mahoney, E.M., and Steinberg, D. (1981): Enhanced macrophage degradation of low density lipoprotein previously incubated with cultured endothelial cells: Recognition by receptor for acetylated low density lipoproteins. Proc. Natl. Acad. Sci. U.S.A., 78, 6499-6503.

32. Prónai, L., Hiramatsu, K., Saigusa, Y., Nakazawa, H. (1991): Low superoxide scavenging activity associated with enhanced superoxide generation by monocytes from male hypertriglyceridemia with and without diabetes. Atherosclerosis, 90, 39-47.

33. Hiramatsu, K., and Nakane, P.K. (1991): Enhanced cholesterol esterification in monocytederived macrophages from diabetic but not hypertriglyceridemic men. J. Clin. Biochem. Nutr., 10, 71-81. 